\title{
PIANO CONCERTO NO. 6 BY ANDRZEJ NIKODEMOWICZ - A SYMPTOMATIC STYLISTIC TRANSFORMATION WITH REGARD TO LATE STYLE?
}

\author{
Ewa Nidecka
}

PhD, Associate Professor; ORCID: 0000-0003-1788-3201; e-mail: enidecka@gmail.com

University of Rzeszów, Poland

\begin{abstract}
The purpose of the article is to analyze one of the seven piano concertos of the great Polish composer of modern times, Andrzej Nikodemovich (1925-2017), in the context of the late style, means of expressiveness and form. In this genre, the composer uses highly dissonant 12-tone sound material and complex rhythmic divisions, complementing the rhythms, thereby creating a dense sound structure.

Ultimately, they contain a recognizable stylistic idiom, the essence of which is lyricism and expression. It is the result of a permanent variability and diversity and the application of development at the microform stage.

Piano Concerto No. 6 is slightly different from earlier works of this composer. Comparing all seven piano concertos, the No. 6 has one distinctive feature: it contains elements of polyphony technique. Andrzej Nikodemovich often used the aforementioned technique, in religious cantata. This is an appeal to traditional baroque music. The methodological basis of this article is the use of a systematic analytical approach with the allocation of musical, historical and textual approaches, which allows one to distinguish the leading features of late style in the works of the composer. The scientific novelty of this article is the awareness of the symptomatic and stylistic transformation of the late style in the works of the composer as an important contributing to his work, the work is first scientifically examined from an eponymous position. Conclusions. The composer skillfully combines the technique of polyphony with lyrical and expressive musical material that dominates the work. Accordingly, this is a symptomatic change within the framework of the late style of the composer's works.
\end{abstract}

Keywords: Andrzej Nikodemowicz; Polish piano concerto; Polish music of the XXI-st century; contemporary music

\section{Introduction}

The piano works by Andrzej Nikodemowicz (1925-2017) are undoubtedly a fascinating part of the composer's oeuvre. The very fact that the vast majority of more important piano works, especially the seven concertos, originated in the late period of his artistic creation 
(1994-2007) begs the following questions: what was the reason why the composer reached for them so late? Although he was a pianist, why didn't he compose such a vast number of concertos earlier? One explanation might be that his artistic creation in his hometown, the beloved Lviv, was considerably limited due to the operation of the communist regime until $1980^{1}$ and with time it became almost impossible. The experience of iniquity inflicted by the communist authorities ${ }^{2}$ had influence on the creation of numerous religious pieces showing the sinfulness and the moral decay of Man, praying for forgiveness. Faith in higher moral values became the driving force unleashing the creative impulse. The composer reminisces about those times in his article Moje Iwowskie lata [My Lviv years], in which he states:

Among other things I wrote, in utter consternation, a lot of sacral music, which I could not reveal. I wrote it, however, out of inner need. Only after I came back to Poland, the works could see the light of day [transl. mine] (Nikodemowicz, 2004, p. 195).

\section{Analysis of recent researches and publications}

The articleuses the materials of publication of modern authors (Drahan M., Örmeny J.,Tomaszewski M.), also Nikodemovich A. and analyzes the program of the festivals.

What can be inferred from the statements made by the renowned Ukrainian pianist Myroslaw Drahan is that all concertos were written for the excellent interpreter of Nikodemowicz's works, the pianist of Hungarian origin living permanently in Lviv, Jozsef Örmeny. He was a well the first performer of Piano Concerto No. 1 (1994), for whom Nikodemowicz altered Violin Concerto (1973), opening a series of later piano concertos and the majority of the composer's works composed for this instrument. Drahan mentioned also another matter concerning the artistic inspiration of the composer. The successful performance of the works by Nikodemowicz at festivals have always widely resounded among those who respected the composer's talent, which, in turn, led to renewed upsurges of creative energy. The very performers inspired the composer to write more works for them. An example might be the piano concertos written for Jozsef Örmeny [transl. mine] (Drahan, 2018, p. 72).

Jozsef Örmeny, in turn, stated once that when he performed the first work by Nikodemowicz, 4 medytacje [Four meditations] for the piano (1986), it led to a pleasant reaction on the composer's part: a surprise was how the pianist can read his work. As Örmeny reminisces, the concerto was a beginning of a creative friendship. Until 2017 Örmeny was the main interpreter of the first five piano concertos by Nikodemowicz, which makes him the top performer of works within this genre ${ }^{3}$. Another reason for the creation of other piano concertos was the composer's dissatisfaction with the final sound of his

\footnotetext{
${ }^{1}$ The year 1980 was special for the composer since at that time, being unable to cope with the harassment of the communist regime, with his family, he moved to Lublin which became his new home and a source of artistic inspiration.

2 In 1973 Andrzej Nikodemowicz lost his job in the Lviv conservatory; all recordings of his works were deleted from the Lviv radio files. In the years 1950-1980 his works were prohibited from being published (Nidecka, 2010, p. 102)

3 Apart from Örmeny, Nikodemowicz's piano concertos were also performed by Joanna Domańska Piano Concerto No.4 at the 5th International Festival "Andrzej Nikodemowicz - time and sound" (2016), and the Hungarian pianist, Zoltàn Füzesséry - Piano Concerto No. 7 at the second edition of the Festival "Andrzej Nikodemowicz - time and sound" (2013); (Örmeny, 2018, p. 101-102; Festival programs "Andrzej Nikodemowicz - time and sound" 2012-2017).
} 
works. It has to be mentioned that he was an incredibly strict evaluator of his own work, which resulted in continuous pursuit of the one and only original sound.

\section{The purpose of the article}

Taking into consideration the fact that piano concertos by Andrzej Nikodemowicz were created relatively recently ${ }^{4}$ and until now (2019) they have not yet been published, they were not the subject of scientific research except for a few authors' contributions ${ }^{5}$. The present article is therefore the first attempt at scientific elaboration of the eponymous work.

\section{Presentation of the main material}

Piano Concerto No. 6 in the context of late style

Piano Concerto No. 6 by Andrzej Nikodemowicz is the penultimate concerto from all seven works, written by the composer for this instrument. This piece was written in 2007, during the happy years when the composer's career was somehow sanctioned within the Polish musical milieu, although the presence of his works on musical stages, except for Lublin, was not satisfactory. Still, Andrzej Nikodemowicz, when he was writing this work, had already been a recognized, award-winning author, and to some extent, fulfilled. His major awards received in 2007 include: the award from the President of Lublin (1999), The Polish Composers' Association (2000), the award from the Minister of Culture and National Heritage (2000), The Musical Award of the City Lublin (2002), a medal and a diploma "Pro Ecclesia et Pontifice" from the pope John Paul the Second (2003), a distinction of the Ukrainian cultural magazine "Ji" for intellectual courage (2005). Moreover in 2005 the composer obtained the title of Professor honoris causa of the Lviv National Musical Academy ${ }^{6}$. The year 2007 concludes creation of the works of the genre of piano concerto with the last Piano Concerto No. 7.

Mieczysław Tomaszewski characterizes "late style" ("last style") as a perceptible distinctiveness from the earlier works, from the individual style which preceded. He continues by highlighting the importance of intent listening of the work: full and absolute, without any a priori presumptions until one almost "revels in sound" (Tomaszewski, 2003, p. 9, 49-50). Considering the piano concertos by Andrzej Nikodemowicz, the following questions could be asked: is it possible to feel the presence of late style in the composer's works? If so, what are the symptoms? In case of piano concertos by

\footnotetext{
${ }^{4}$ Six out of seven piano concertos, except for the first one, were composed in the years 2002-2007.

5 These include the articles: T. Jasiński, "III Koncert fortepianowy" Andrzej Nikodemowicza. Muzyka piękna, [in:] "Annales Universitatis Mariae Curie-Skłodowska", Lublin - Polonia, 2007 vol. V. Sectio L Artes; and E. Nidecka, I Koncert fortepianowy Andrzeja Nikodemowicza - ukryte pragnienie wolności, "Notes Muzyczny" 2018 No. 1 (9), II Koncert fortepianowy Andrzeja Nikodemowicza - poszukiwanie oryginalnego brzmienia, "Prace Naukowe Akademii im. Jana Długosza w Częstochowie. Edukacja Muzyczna" XII (subsequent articles by the author on the subject of Nikodemowicz's piano concertos, i.e. concerto no. 4 and 5 , have already been submitted for publication).

${ }^{6}$ The received awards I mention in Muzyka sakralna w twórczości..., p. 103. Major awards received by Andrzej Nikodemowicz include: the honorary membership in the Polish Composers' Association (2015); see the valediction of the president of ZKP, Mieczysław Kominek Czas i dźwięk. Spotkania z Andrzejem Nikodemowiczem, p.179.
} 
Andrzej Nikodemowicz, the category of late style includes the most of works in this genre since except for Piano concerto No. 1 (1994), as mentioned above, all the remaining concertos originated in 2000, so when the composer was over 70 . As a consequence, the only early Piano concerto No. 1 is said to be an adaptation of Violin Concerto No. 1 from 1973. The most important pillars of the composer's works, distinctly visible against the background of his oeuvre, are as follows: melodic-rhythmic complications, permanent changeability, invariance of musical material, preference of traditional form (this last element slightly evolved in the late works by Nikodemowicz), which results in melodic-rhythmic dispersion, changeability and harmonic complications, lack of thematic perspicuity, focus on the color factor, and in case of the piano concerto genre - the application of color of motion in the piano section. However, it should be mentioned the approach used in the last years of his creative activity.

In order to notice clearly the differences in style, it is enough to compare Piano concerto No. 6 with Concertino on the themes of Sonatina in C-major by M. Clementi for the piano and 8 woodwinds (1967). The two pieces are separated by 40 years. Concertino on the themes of Sonatina in $C$-major is a special work as it represents a relatively rare stylistic current in Nikodemowicz, defined as a parodical variety of neo-classicism. Nikodemowicz's aesthetic basis was influenced at some point by the works of K. Szymanowskyi, A. Skriabin, and partly also by B. Bartók and I. Strawiński. As early as during his stay in Lviv, so in the years of the Soviet sociopolitical policy, the composer, as a lecturer at the Lviv conservatory, led a student group which from time to time performed various musical pieces. In 1968 this band performed The Soldier's Tale (a piece by Igor Strawiński, a composer not performed in Lviv at that time), directed by Stefania Pawłyszyn (Andrzej Nikodemowicz was in charge of the musical aspects of the performance) (Nidecka, 2010, p. 101). For ideological reasons, the works by Strawiński were deemed to be unimportant and not worthy of any attention. The staging of this work was an act of courage, which might result in falling in disfavor with the authorities, for which Nikodemowicz was a perennial problem due to his religious involvement and uncompromising views. A consequence of this attitude was Nikodemowicz's dismissal and his decision to leave Lviv and move permanently to Poland (to Lublin; see footnote no. 2). Undoubtedly, the composer knew Strawiński's work and could have acquired some of the elements of its musical language, which can be seen in Concertino on the themes of Sonatina in C-major by M. Clementi.

In Concertino it is possible to notice a highly advanced transformation of the fourbar fragment of the theme of Allegro from the first part of Sonatina in C-major op. 36 No. 1, which retains in short spaces the main key (C major), but with the modification of the scale in which the fourth step was raised, exposing the Lydian fourth. The elements acquired from Strawiński inscribed into the parodistical variety of neoclassicism include atomization or de-idiomatisation of musical language consisting in its disruption into microelements taken out of the context and the deformation of these microelements by harmonic and instrumental procedures (Piotrowska, 1982, p. 5,61-64). An example of the said microelement is the fragment of the theme of the above sonatina by $\mathrm{M}$. Clementi. As a result, in Concertino to the foreground come multifarious sound-texture contexts with a substantial dose of wit and irony. Here it 
is not possible to find a high degree of sound sophistication, rich shading of sound within a uniform sound range, e.g. color of motion in the piano section, found in piano concertos, so characteristic of the late style of Andrzej Nikodemowicz. This example clearly shows the transformation of the composer's style, in which Nikodemowicz drifted from neoclassical elements to lyrical and expressive qualities, by operating within different shades of mood, which came to be the main stylistic feature and, to a lesser extent, energetic qualities, drawn from a new type of energetics - thanks to B. Bartók and I. Strawiński.

The internal structure of the work

Analyzing Piano concerto No. 6 by Nikodemowicz, it is possible to discern certain symptomatic changes in style, which can be seen not only in relation to works written much earlier, but also taking into account earlier piano concertos, which, as mentioned above, originated in the late period of the composer's activity. This concerto contains fewer contrasts in the projection of musical material, resulting in the change in character. First of all, Nikodemowicz resigned from static fragments, suspension of musical time, so distinctive in previous works within this genre. Apart from several exceptions, he also resigned from heavily energetic elements exposing vigorous rhythmicity that could be traced back to Bartók. Ultimately, Piano concerto No. 6 is a more uniform work with regard to musical material, which is obviously connected to its lower diversity and contrastivity. Simultaneously, processual development and smoothness of musical material is still applied, which consists in the lack of sudden agogic and dynamic changes or alterations of motives and musical expression. It can be stated that the utilized material is more uniformised as compared to Piano Concerto No. 1 (Nidecka, 2018, p. 130, 135, 147). In the discussed work the emotions are slightly toned down, so the style concitato is discontinued although it occurred in almost all piano concertos.

In the scope of the musical material, it is possible to discern two main types: the counterpoint type shaped based on polyphonic technique and the lyrical-expressive type. Taking into consideration all piano concertos, the latter type, consisting in the dispersed projection of sounds of different agogic values, utilizing e.g. color of motion, is dominant and decides about the essence of the style in Nikodemowicz's piano concertos.

Polyphonic fragments in the musical material with elements of imitation make Piano concerto No. 6 distinct from other works within this genre. Andrzej Nikodemowicz frequently uses the polyphonic technique, especially in religious works. For example, the canonic technique was applied in the work dedicated to the Pope John Paul the Second Antyfona do Najświętszej Maryi Panny [Antiphony for the Blessed Virgin] (1982) in the choir section.

Imitative fragments of Piano concerto No. 6 first appeared in woodwinds, starting from the 50th bar. The initial motive of the oboe section plays the role of the main theme:

A relevant characteristic of the theme is its construction. Namely, at the beginning of the theme there is a distinctive major septimal interval, the favorite interval frequently utilized by the composer as a structural element of themes, motives and various musical sequences. The main theme undergoes imitation through subsequent 
Example 1. A. Nikodemowicz, Piano Concerto No. 6, imitation of the main theme in the woodwinds, bars 50-60
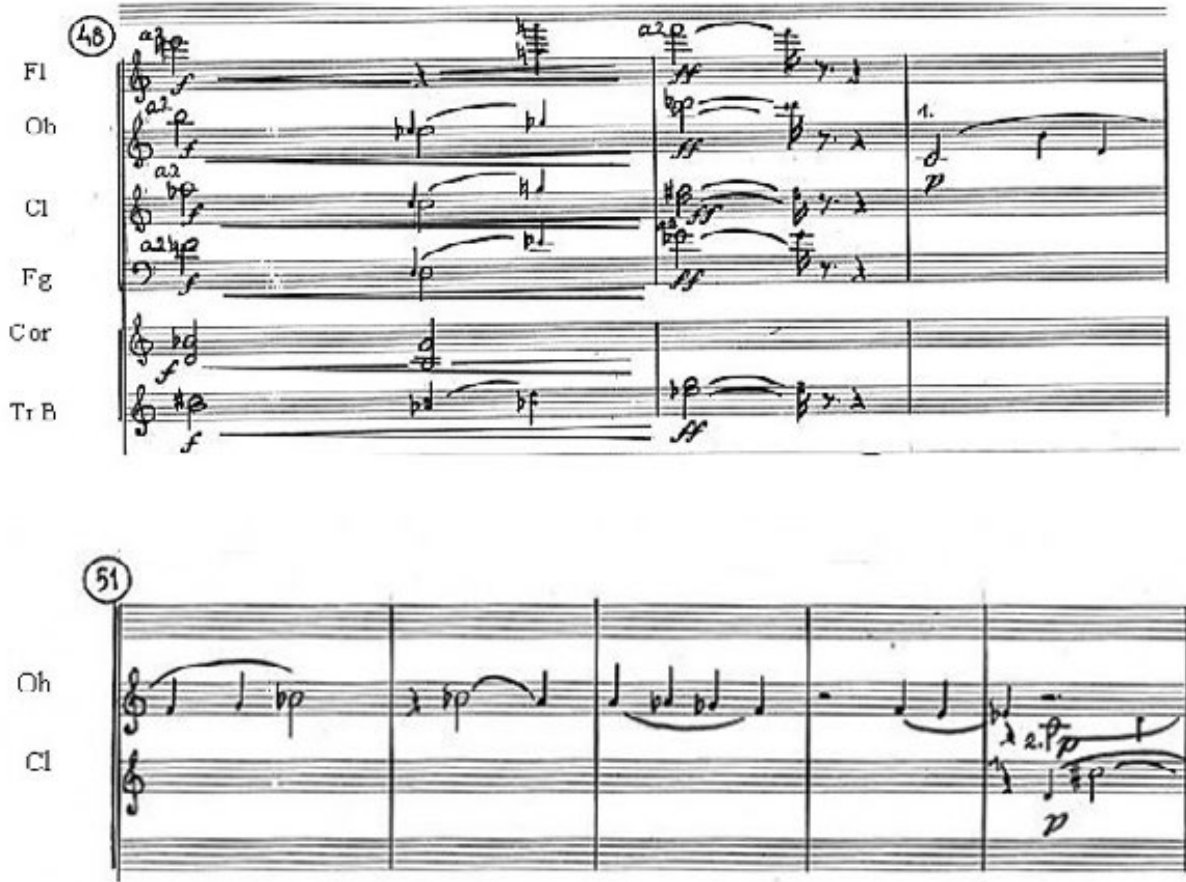

//

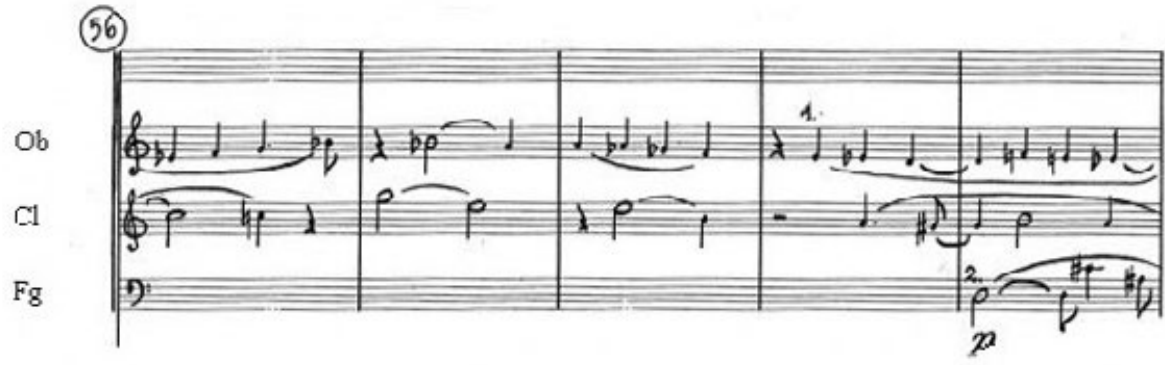

instruments or instrumental groups. The repetitiveness of imitation introduces certain modifications of elements of the theme which most often include the first two bars, in different instrumental groups, e.g. the strings (from bar 67) and French horns (from bar 103). Taking into consideration all the piano concertos by the author, it is one of few examples of such a visible application of the imitation technique, which became a new structural element. Its utilization is undoubtedly a marked turn towards the tradition of baroque. Moreover, the composer aptly combines polyphonic technique 
with the already introduced lyrical-expressive material (example in the fragment from bar 73).

Counterpoint elements separate the projection of the second type of musical material of lyrical-expressive character. The last type is characterized by diversity and rhythmic complication and sound dispersion, which constitute, as we have repeatedly underlined, the essence of Andrzej Nikodemowicz's style. As with the previous piano concertos, the wealth of colorful musical material is obtained by the composer as a result of overlapping many musical elements such as: rhythmic complication, in particular overlapping of double and triple meter and continuous changeability and substantial dispersion of the pitch of sound through numerous figurations in the piano section. The examples below show both the diversity and variantabilty of the musical material of the lyrical-expressive type:

Example 2. A. Nikodemowicz, Piano Concerto No. 6, a variety of projection of lyricalexpressive material in the piano section

a) bars 95-96

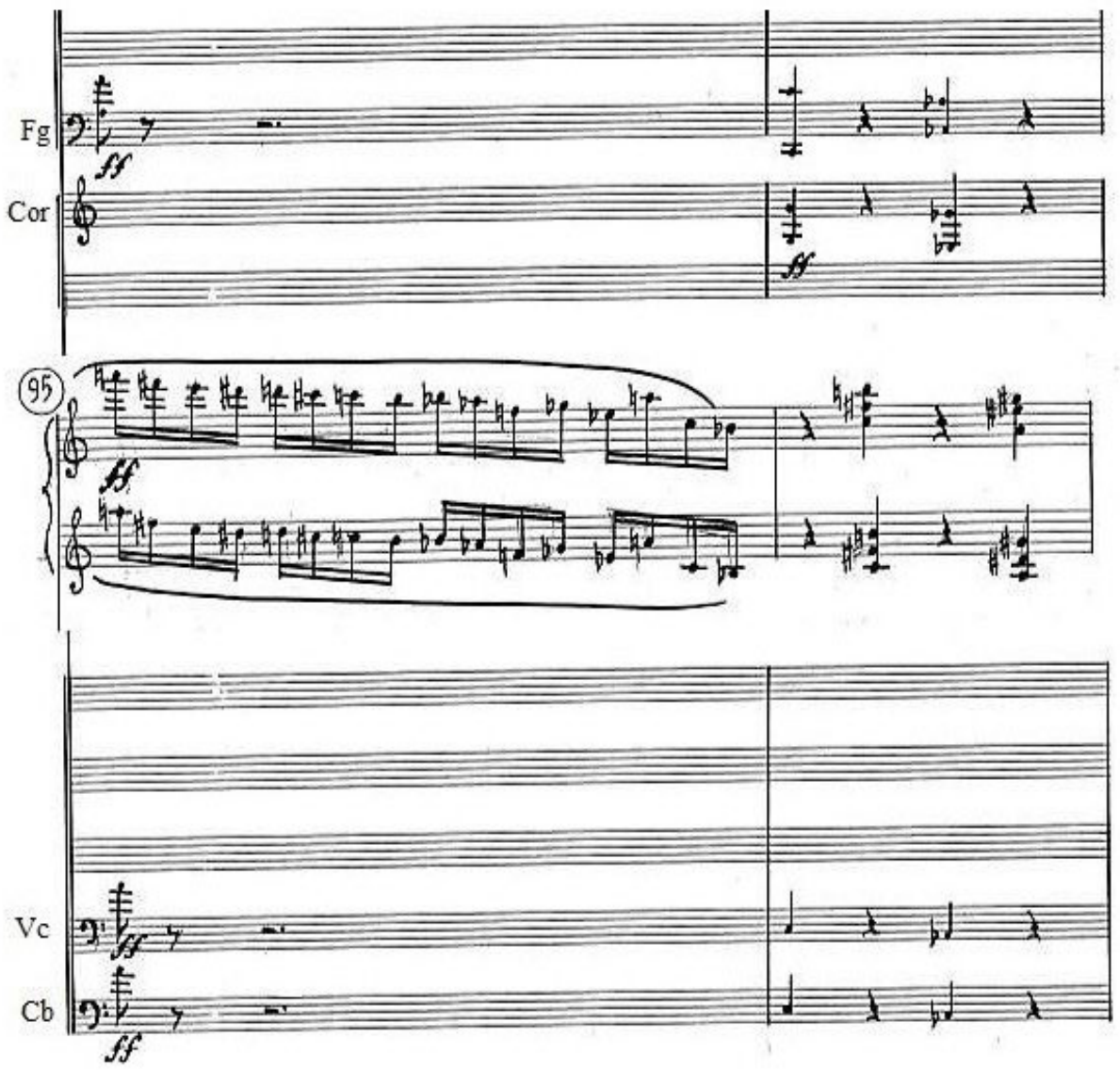




\section{TEOPIЯ}

ISSN 2616-7581 (Print)

ISSN 2617-4030 (Online)
Вісник Київського національного університету

культури і мистецтв. Серія: Музичне мистецтво
$2019 \cdot 2(1) \cdot 35-49$

b) bars $111-112$, solo piano

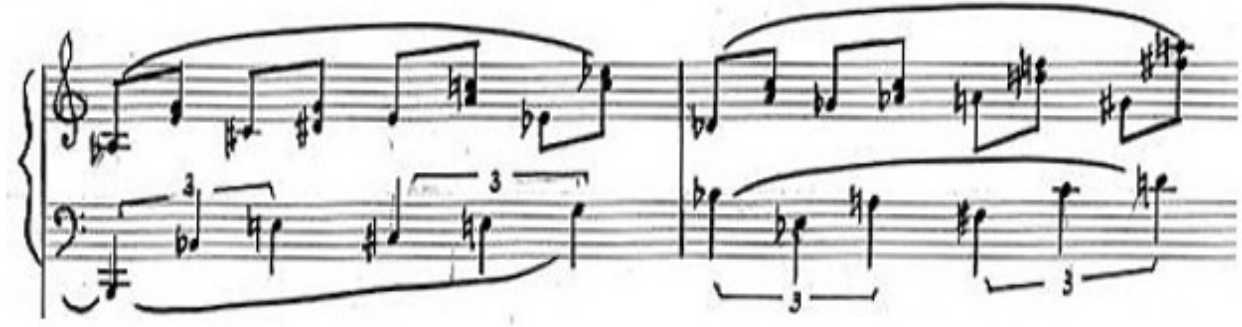

c) bars $113-114$

(113)

F1

$\mathrm{Ob}$

$\mathrm{Cl}$<smiles>C1=CC=C1</smiles>

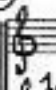

1 .

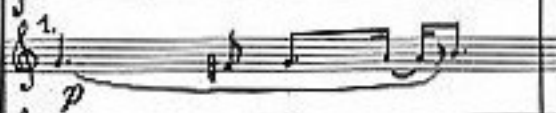

(5)

$\mathrm{Fg}$

Cor
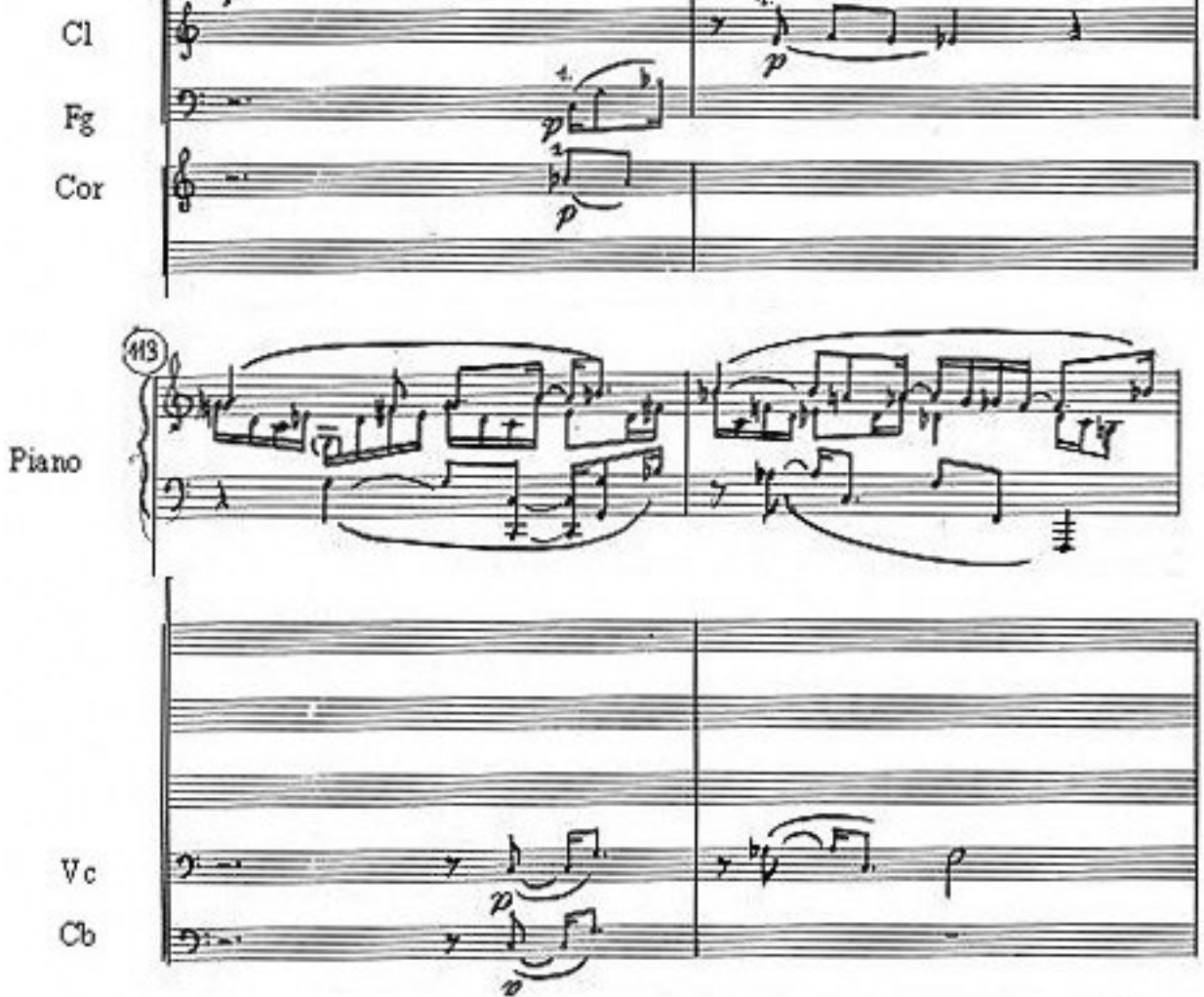
A solo instrument to a large extent shapes the sound aspects of a work. The perceptible texture-rhythm diversity and the simultaneous smooth changeability connected with dispersion of the pitch of sounds create colorful sequences, through the utilization of e.g. the colour of motion with virtuoso characteristics. The orchestra usually creates a subtle, pastel background, especially thanks to the strings, possibly doubling reoccurring melodic sequences in the solo instrument section or develops the musical thought introduced earlier.

Taking into consideration the fact that the projection of the musical material has changeable shape, undergoes continuous fluctuation and repeats themes and motives of different types in an invariant form, the shape of the concerto does not contain a clear division into visibly separated parts. It is occasioned by the lack of unequivocally determined tempo and character, delineating, for instance, a uniform part which is fast or slow as is the case with a classical concerto. Nevetrtheless, it is possible to discern a certain outline of three-partedness which originated as a result of introduced texture differentiation.

Fig 1. The formal flow of Piano Concerto No. 6 by Andrzej Nikodemowicz

\begin{tabular}{|c|c|c|}
\hline $\begin{array}{c}\text { part I } \\
\text { bars 1-48 } \\
\text { lyrical- } \\
\text { expressive }\end{array}$ & $\begin{array}{c}\text { part II } \\
\text { bars 49-103 } \\
\text { with elements of } \\
\text { polyphonic } \\
\text { technique }\end{array}$ & $\begin{array}{c}\text { part III } \\
\text { bars 104-192 } \\
\text { lyrical- } \\
\text { expressive }\end{array}$ \\
\hline
\end{tabular}

Although the texture freely shaped creates a changeable whole, some boundary lines are introduced by the counterpoint technique which is the vehicle of the main theme and, as mentioned above, constitutes a distinctive element with regard to the lyrical-expressive material. It has to be mentioned that in the second part the counterpoint texture is intertwined with lyrical-expressive material. Material of episodic character appears also in the second part, leading to one of two the largest culminations in the work, in the bars 95-100. The culmination consists in dramatic dialogues between the piano and the whole performance 'apparatus'. In other fragments the texture of this part sometimes evolves towards more static chorale blocks in the strings and winds. Here the expression is shaped on the basis of resounding blocks of long rhythmic values. The second big culmination occurs in the final chords at the end of the concerto. The composer introduces also a few minor culminations, which processually shape the musical narrative full of various shades of sound.

Changes in texture substantially influence the increased significance of instrumental groups of the orchestra, especially of the winds and, to a lesser extent, the strings as there are many dialogues between the piano and the above mentioned groups which take control of the musical thought, continue it or mutually develop.

Despite the material fluctuations, the essential feature of the discussed work is texture motive coherence resulting from the repeatability of themes and subsidiary thoughts. Apart from numerous repetitions of the main theme occurring in the polyphonic texture, another example having an impact on the coherence of the work 
is the multiple introduction of a two-bar subsidiary theme, the first part of which is developed in simultaneous thirds (the so called third theme)?

Example 3. A. Nikodemowicz, Piano Concerto No. 6, bars 45-46, the subsidiary theme of the third

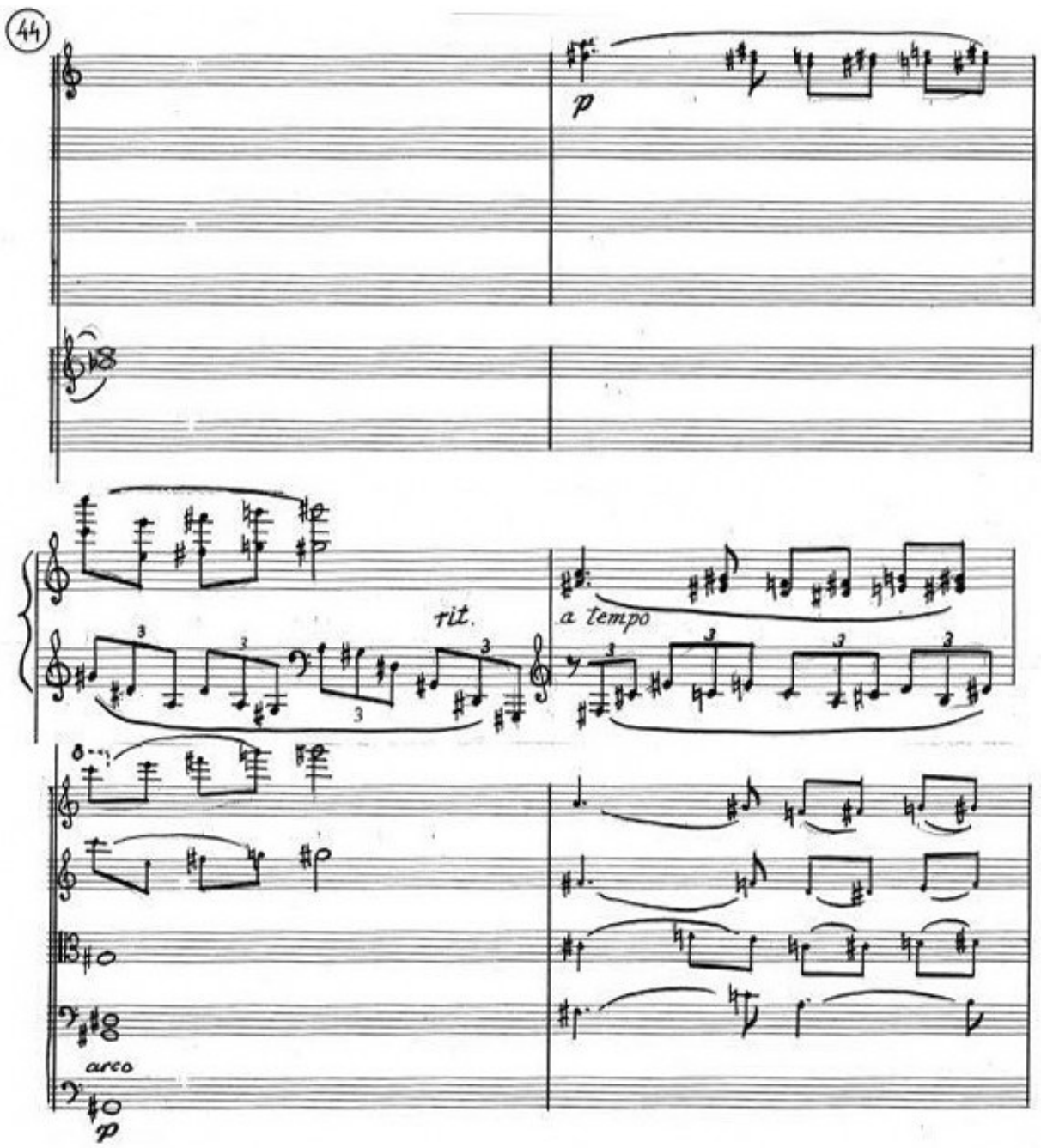

For the first time the initial part of the subsidiary theme appears in bar 41 in the piano section and in cellos and double bass, while it is fully introduced in bars 45-46 in the flute section, piano and strings (example 3 ). Its characteristic feature is the chromatic, undulating shifts. Another, slightly modified version of the subsidiary theme occurs subsequently in bars 173-174, in the performance apparatus extended with French

\footnotetext{
7 The second part of the third theme consists of rising fourths which undergo modification in subsequent repetitions.
} 
horns. As a result, the coherence of the work is influenced by the continuous endeavor to create new variants of themes and motives and processing their structural elements.
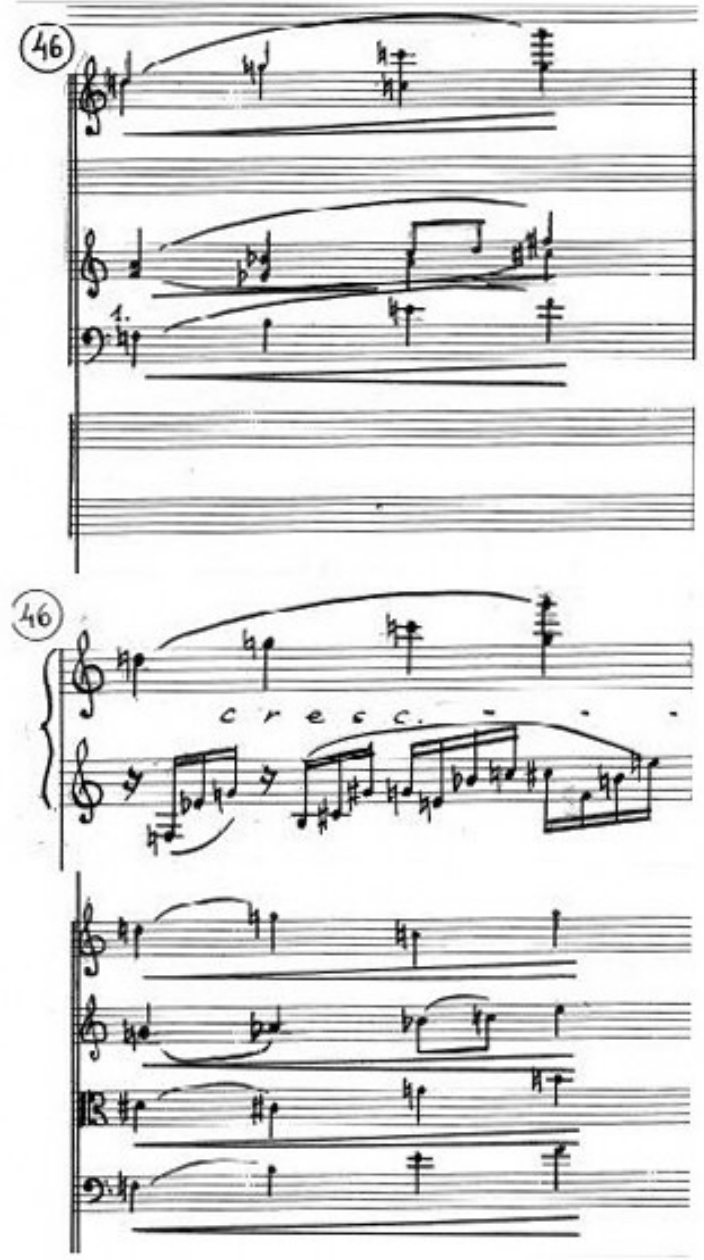

To sum up the above analytical comments, the most relevant stylistic features, which can be discerned in the concerto are as follows:

1. rhythmic complication (in particular, overlapping double and triple meters)

2. full atonalism with the application of the chromatic factor

3. dissonance harmonics

4. texture-motive coherence

5. highlighting the color qualities and timbre nuances (shading of timbres)

6. disposing of expression contrasts

7. dynamic-agogic and expressive changeability applied based on the principle of processual smoothness 


\section{8. permanent development at the stage of microform}

9. building the texture based on two types of shaping of the musical material

- lyrical-expressive one, which is changeable with regard to the dynamic-agogic, colour and timbre aspect (through frequent register change, especially in a solo instrument) and character

- counterpoint with elements of polyphonic technique - as a new element of structure compared to the previously composed piano concertos.

On the one hand, the implementation of the composer's concept of the piece shows the utilization of the timbre possibilities within the already shaped style, on the other, a certain return to tradition. The application of elements of the polyphonic technique is a rare feature in the history of the piano concerto genre in case of Polish composers of the second half of the 20th century and 21st century. In Andrzej Nikodemowicz's music it was more often utilized in religious works: it appeared in piano concertos for the first time.

\section{Conclusions}

\section{A few remarks about the reception of piano concertos by Andrzej Nikodemowicz}

Piano concertos by Andrzej Nikodemowicz have not been performed by many pianists as they pose a serious technical challenge for the interpreter and they have not been published in the form of musical notation. As mentioned above, the piano works were performed by the Hungarian pianist living permanently in Lviv, Jozsef Örmeny, who until 2017 interpreted the first five concertos and Joanna Domańska, who performed for the first time Piano Concerto No. 6 at the fifth edition of the Festival "Andrzej Nikodemowicz time and sound" on the 25th of September 2016 in Lublin. The last Piano Concerto No. 7 was performed by another Hungarian pianist of the young generation, Zoltan Füzesséry at the second edition of the above festival on the 22nd of September 2013. It is possible to observe the high popularity of Nikodemowicz's works among Hungarian and Ukrainian artists who attempt to perform these difficult works both in the past and the present. In recent years Polish pianists have also become more and more interested in the piano works by Andrzej Nikodemowicz, which can be seen in the festival programs ${ }^{8}$. The yearly editions of the festival (in Lublin since 2012) have become the most important cyclical event in Poland which promotes Andrzej Nikodemowicz's oeuvre. Both piano concertos and other works by the composer are the main item in the program of the festival's every edition. The works by Nikodemowicz are also performed at other concerts and festivals in Poland and abroad, e.g. at the International Festival of Contemporary Music in Lviv, where the composer has made his mark in the musical circles.

Andrzej Nikodemowicz's music has undoubtedly found recognition as a part of the contemporary Polish music. I will conclude with a quote from the composer's daughter, Małgorzata Nikodemowicz, who characterizes it in a concise and adequate way:

His music surely cannot be described as easy to accept. But I get the impression that as it often happens - it precedes at least one generation [transl. mine] (Nikodemowicz, 2018, p. 20).

\footnotetext{
${ }^{8}$ Ukrainian pianists who have Nikodemowicz's works in their repertoire include Myroslaw Drahan, Oksana Rapita: Polish ones - apart from Joanna Domańska - Michał Drewnowski, Marek Szlezer, Zbigniew Raubo, Piotr Banasik. Work by this composer are also in the repertoire of Asian pianists e.g. Mei Yi Foo from Malaysia (Festival Programs "Andrzej Nikodemowicz - time and sound" 2012-2018).
} 
It might be concluded that Andrzej Nikodemowicz's music requires aesthetic, intellectual and cultural maturity.

\section{References}

Drahan, M. (2018). Muzyka przepełniona duchowością [Music filled with spirituality]. In T. KsięskaFalger (Ed.), Czas i dźwięk. Spotkania z Andrzejem Nikodemowiczem [Time and sound. Meetings with Andrzej Nikodemowicz] (pp. 71-73). Lublin: Gaudium [in Polish].

Festival programs «Andrzej Nikodemowicz - czas i dźwięk» 2012-2018 [Festival programs "Andrzej Nikodemowicz - time and sound" 2012-2018] [in Polish].

Nidecka, E. (2010). Muzyka sakralna w twórczości Andrzeja Nikodemowicza [Sacral music in the works of Andrzej Nikodemowicz]. Rzeszów: Wydawnictwo Uniwersytetu Rzeszowskiego [in Polish].

Nidecka, E. (2018). I Koncert fortepianowy Andrzeja Nikodemowicza - ukryte pragnienie wolności [Piano Concerto No. 1 by Nikodemowicz - a hidden desire for freedom]. Notes Muzyczny. 1(9), 214-222 [in Polish].

Nikodemowicz, A. (2004). Moje Iwowskie lata [My Lviv years]. Annales Universitatis Mariae CurieSkłodowska Lublin - Polonia, 2 (L), 189-198 [in Polish].

Nikodemowicz, M. (2018). Ojciec. In T. Księska-Falger (Ed.), Czas i dźwięk. Spotkania z Andrzejem Nikodemowiczem [Time and sound. Meetings with Andrzej Nikodemowicz] (pp. 21-24). Lublin: Gaudium [in Polish].

Örmeny, J. (2018). Podarował światu piękno i miłość [He gave the world beauty and love]. In

T. Księska-Falger (Ed.), Czas i dźwięk. Spotkania z Andrzejem Nikodemowiczem [Time and sound. Meetings with Andrzej Nikodemowicz] (pp. 101-106). Lublin: Gaudium [in Polish].

Piotrowska, M. (1982). Neoklasycyzm w muzyce XX wieku [Neoclassicism in 20th-Century Music]. Warszawa: Akademia Teologii Katolickiej [in Polish].

Tomaszewski, M. (2003). Muzyka w dialogu ze słowem [Music in dialogue with the word]. Kraków: Akademia Muzyczna [in Polish].

\section{КОНЦЕРТ ДЛЯ ФОРТЕПІАНО № 6 АНДЖЕЯ НІКОДЕМОВИЧА - СИМПТОМАТИЧНА ЗМІНА СТИЛЮ ЩОДО СТИЛЮ ПІЗНЬОГО ПЕРІОДУ?}

\section{Ева Нідецка}

кандидат мистецтвознавства, доцент; ORCID: 0000-0003-1788-3201; e-mail: enidecka@gmail.com Жешувський університет, Жешув, Польща

\section{Анотація}

Метою статті $\epsilon$ аналіз одного з семи фортепіанних концертів видатного польського композитора сучасності Анджея Нікодемовича (1925-2017), в контексті пізнього стилю, з погляду засобів виразності та форми. У цьому жанрі композитор використовує сильно 
дисонуючий 12-тональний звуковий матеріал і складні ритмічні поділи, комплементарні ритми, створюючи тим самим щільну звукову структуру. В кінцевому підсумку, вони містять впізнавану стилістичну ідіому, суть якої - ліризм і експресія. Це результат постійної мінливості і різноманітності застосування розробки на рівні мікроформ.

Фортепіанний концерт № 6 дещо відмінний від більш ранніх робіт композитора. Порівнюючи всі сім фортепіанних концертів, саме шостий має одну відмітну особливість: цеелементитехнікиполіфонії. Згаданутехніку Анджей Нікодемовиччастовикористовував у релігійних кантатах. Це звернення до традиційної барокової музики. Методологічною основою даної статті $€$ застосування системного аналітичного підходу з виділенням музикознавчого, історичного та текстологічного підходів, що дозволяє виокремити провідні риси пізнього стилю у творах композитора. Науковою новизною даної статті $€$ усвідомлення симптоматичної зміни стилю пізнього періоду у творах композитора як важливої складової його творчості, концерт вперше науково розглядається з епонімічної позиції. Висновки. Техніку поліфонії композитор вміло поєднує з лірично-експресивним музичним матеріалом, який домінує у творі. Відповідно, це є показовою зміною в рамках пізнього стилю композитора.

Ключові слова: Анджей Нікодемович; польський фортепіанний концерт; польська музика XXI століття; сучасна музика

\section{КОНЦЕРТ ДЛЯ ФОРТЕПИАНО № 6 АНДЖЕЯ НИКОДЕМОВИЧА - СИМПТОМАТИЧЕСКИЕ ИЗМЕНЕНИЯ СТИЛЯ ОТНОСИТЕЛЬНО СТИЛЯ ПОЗДНЕГО ПЕРИОДА?}

\section{Эва Нидецка}

кандидат искусствоведения, доцент; ORCID: 0000-0003-1788-3201; e-mail: enidecka@gmail.com Жешувский университет, Жешув, Польша

\section{Аннотация}

Целью статьи является анализ одного из семи фортепианных концертов выдающегося польского композитора современности Анджея Никодемовича (1925-2017), в контексте позднего стиля, с точки зрения средств выразительности и формы. В этом жанре композитор использует сильно диссонирующий 12-тональный звуковой материал и сложные ритмические разделения, комплементарные ритмы, создавая тем самым плотную звуковую структуру. В конечном счете, они содержат узнаваемую стилистическую идиому, суть которой - лиризм и выражение. Это результат постоянной изменчивости и разнообразия применения разработки на уровне микроформ.

Концерт для фортепиано № 6 немного отличается от ранних произведений композитора. Сравнивая все семь фортепианных концертов можно отметить, что в данном концерте есть одна отличительная особенность: он содержит элементы техники полифонии. Эту технику использовал Анджей Никодемович в своих религиозных кантатах. Это относится к традиции барочной музыки. Методологической основой данной статьи является применение системного аналитического подхода 
с выделением музыковедческого, исторического, текстологического подходов, что позволяет выделить ведущие черты в поздних произведениях композитора. Научной новизной данной статьи является осознание симптоматического изменения стиля позднего периода в произведениях композитора как важной составляющей его творчества, произведение впервые научно рассматривается с эпонимической позиции. Выводы. Технику полифонии композитор умело сочетает с лирически-выразительным музыкальным материалом, который доминирует в произведении. Соответственно, это и является показательным изменением в рамках позднего стиля произведений композитора.

Ключевые слова: Анджей Никодемович; польский фортепианный концерт; польская музыка XXI века; современная музыка 